\title{
Foliage applied boron improves the panicle fertility, yield and biofortification of fine grain aromatic rice
}

\author{
A. Rehman ${ }^{1}$, M. Farooq ${ }^{1,2,3^{*}}$, Z. Ata Cheema ${ }^{1}$, A. Nawaz ${ }^{1}$ and A. Wahid ${ }^{4}$ \\ ${ }^{1}$ Department of Agronomy, University of Agriculture, Faisalabad-38040, Pakistan. ${ }^{2}$ The UWA Institute of Agriculture, The \\ University of Western Australia, 35 Stirling Highway, Crawley WA 6009, Australia. ${ }^{3}$ College of Food and Agricultural Sciences, \\ King Saud University, Riyadh 11451, Saudi Arabia. ${ }^{4}$ Department of Botany, University of Agriculture, Faisalabad-38040, \\ Pakistan.*Corresponding author:farooqcp@gmail.com
}

\begin{abstract}
Boron (B) deficiency in rice field is becoming a common problem in South Asia. Correcting B deficiency in rice has potential to improve the rice productivity. Foliage application of $\mathrm{B}$ is an easy and effective way to resolve this problem. This study was conducted to evaluate the influence of foliage applied $(0.16,0.24,0.32,0.40$ and $0.48 \mathrm{M})$ $\mathrm{B}$ on leaf elongation, tillering, water relations, yield and B grain enrichment of rice cultivars Super Basmati and Shaheen Basmati. Foliage applied B improved leaf elongation, tillering, leaf chlorophyll contents, water relations, grain yield, yield-related traits and B grain contents with simultaneous decrease in panicle sterility. However, foliage application of $0.32 \mathrm{M} \mathrm{B}$ was the most effective in this regard. An increase in leaf and grain B contents was observed with increase in B concentration in the foliar spray. There was no difference between the cultivars for grain yield; however, Shaheen Basmati had more grain weight, and grain and leaf B contents than Super Basmati. Boron foliage application $(0.32 \mathrm{M} \mathrm{B})$ proved an effective way to correct B deficiency in rice. Improvement in grain yield by $\mathrm{B}$ application was attributed to increase in grain size and decrease in panicle sterility.
\end{abstract}

Keywords: Boron, chlorophyll, foliar application, rice, sterility, water relations

\section{Introduction}

Boron (B) deficiency is spreading in most of rice growing soils. Although considered tolerant, rice suffers with B deficiency resulting in substantial yield loss (Cakmak and Römheld, 1997; Rashid et al., 2009). Several factors including drought, low soil $\mathrm{pH}$, calcareous nature of soil, and B leaching and fixation have been considered as the possible reasons of B deficiency (Goldberg et al., 1997; Shorrocks, 1997).
Physiologically, B deficiency may result in loss of integrity and function of membrane, and decrease in cell wall stability resulting in structural damage in plants (Parr and Loughman, 1983; Cakmak and Römheld, 1997; Blevins and Lukaszewski, 1998). Likewise, B deficiency affects metabolisms of nucleic acid, carbohydrate, protein, indole acetic acid and phenolics (Cakmak and Römheld, 1997). 
Boron deficiency may also persuade leaf structural changes like abnormal stomata and distorted guard cells (Sharma and Sharma, 1987; Blevins and Lukaszewski, 1998) and/or may reduce the stomatal conductance and transpiration rates of plants (Sprague, 1951; Sharma and Sharma, 1987; Sheng et al., 2009). However, reproductive stage of plants is more sensitive to $\mathrm{B}$ deficiency than the vegetative stage (Longbin et al., 2000).

Boron application to rice fields increased rice growth and grain yields in soils low in B (Rashid et al., 2009; Hussain et al., 2012); however, some problems with uptake of B in conditions of low moisture in soil and/ or application of B only upon evident B deficiency symptoms have been found (Dunn et al., 2005). Under such circumstances, foliar fertilization is more effective and economical (Dunn et al., 2005) as this may instantly repair plant tissues damaged specifically from B deficiency (Dunn et al., 2005; Hussain et al., 2012).

Although foliage applied B improves the grain yield of rice (Dunn et al., 2005; Hussain et al., 2012), understanding the physiological mechanism of yield improvement by foliar applied B and its grain biofortification potential is lacking. It was hypothesized that foliar applied B can meet the $\mathrm{B}$ requirement of rice and improves the grain yield, by decreasing the panicle sterility.

This study was therefore conducted to evaluate the influence of foliage applied B on the panicle fertility, grain yield and boron biofortification of fine grain aromatic rice.

\section{Materials and Methods}

Seeds of fine grain aromatic rice cultivars Super Basmati and Shaheen Basmati, used in this study, were obtained from Rice Research Institute, Kala Shah Kakoo, Pakistan and Soil Salinity Research Institute,
Pindi Bhattian, Hafizabad, Pakistan, respectively. The initial seed moisture contents were 8.06 and $8.57 \%$ (on dry weight basis) in cultivars Super Basmati and Shaheen Basmati, respectively. Pre-germinated seeds (10) were sown in $8 \mathrm{~kg}$ soil-filled earthen pots $(45 \times 30 \mathrm{~cm})$ placed in a net house on June 25, 2009 . Experimental soil was sandy loam with $\mathrm{pH}$ 8.2, EC $0.33\left(\mathrm{dS} \mathrm{m} \mathrm{m}^{-1}\right)$, organic matter $0.71 \%, \mathrm{~N} 0.044 \%$, P 5 ppm, K 165 ppm and B 0.45 ppm. Plants were thinned to maintain 5 plants in a pot one week after sowing.

Boron was sprayed on leaves as 0 (control), 0.16 , $0.24,0.32,0.40$ and $0.48 \mathrm{M} \mathrm{B}$ solution one week after sowing using boric acid as a source. Experiment was conducted in completely randomized design in factorial arrangement with five replications. Weather data during course of experiment at experimental site are given in Table 1. Fertilizers were applied at 572, $352,272,100 \mathrm{mg}$ NPKZn per pot using urea $(46 \% \mathrm{~N})$, single superphosphate $\left(18 \% \mathrm{P}_{2} \mathrm{O}_{5}\right)$, sulphate of potash $\left(50 \% \mathrm{~K}_{2} \mathrm{O}\right)$ and $\mathrm{ZnSO}_{4}(35 \% \mathrm{Zn})$, respectively as sources. Whole quantity of PK and $\mathrm{Zn}$ was applied as basal dose; whereas half quantity of $\mathrm{N}$ was applied as basal and other half in two splits at tillering and panicle initiation stages. Pots were irrigated twice in a week to meet the water requirements of the crop.

After B application, number of leaves and tillers were counted daily to determine the rate of leaf and tiller emergence. Likewise, length of $4^{\text {th }}$ and $5^{\text {th }}$ leaf was measured daily to derive the leaf elongation.

Observations on leaf chlorophyll (Chl) contents, plant water relations and leaf $\mathrm{B}$ contents were taken at booting stage (BBCH-scale 41). Leaf chlorophyll contents were determined from flag leaf following Arnon (1949). According to this method, pigments were extracted in $80 \%$ acetone. Concentration of each Chl was determined by measuring the absorbance (A) of the extract at the major red absorption maxima of Chl-a $(\sim 663 \mathrm{~nm})$ and b ( 645 nm) and values were inserted into the following equations:

$$
\text { Chl-a }\left(\mathrm{mg} \mathrm{g}^{-1} \mathrm{FW}\right)=12.70(\mathrm{~A} 663)-2.69(\mathrm{~A} 645)
$$


Chl-b $\left(\mathrm{mg} \mathrm{g}^{-1} \mathrm{FW}\right)=22.90(\mathrm{~A} 645)-4.68(\mathrm{~A} 663)$

Total Chl $\left(\mathrm{mg} \mathrm{g}^{-1} \mathrm{FW}\right)=20.2(\mathrm{~A} 645)+8.02(\mathrm{~A} 663)$

Leaf water potential $\left(\Psi_{\mathrm{w}}\right)$ was determined using pressure chamber (Soil Moisture Equipment Corp., Santa Barbara, CA, USA) from penultimate leaf. Same leaf tissues were frozen, thawed, sap expressed, centrifuged at $5000 \times \mathrm{g}$ and osmotic potential ( $\Psi$ s) was determined with an osmometer (Digital Osmometer, Wescor, Logan, UT, USA). Leaf pressure potential ( $\Psi$ p) was computed as a difference of $\Psi w$ and $\Psi$ s. For relative water contents (RWC), $0.5 \mathrm{~g}$ (Wf) fresh flag leaf samples were taken. These samples were floated on water for $4 \mathrm{~h}$ to get saturated weight (Ws). These leaves were dried for $24 \mathrm{~h}$ at $85^{\circ} \mathrm{C}$ to determine dry weight (Wd). RWC (\%) were calculated as:

$$
\mathrm{RWC}=\left(\mathrm{W}_{\mathrm{f}}-\mathrm{W}_{\mathrm{d}}\right) /\left(\mathrm{W}_{\mathrm{s}}-\mathrm{Wd}\right) \mathrm{X} 100
$$

At maturity, number of tillers was counted. Each plant was harvested and threshed separately to get grain yield. Shaheen Basmati was harvested on October 15, 2009, whereas Super Basmati was harvested on November 11, 2009.

Samples of 1000 kernels were weighed for 1000-kernel weight. Panicle sterility was determined using the following relation:

Panicle sterility $(\%)=[$ Number of total panicles Number of filled panicles /Number of total panicles] $\mathrm{x} 100$

For leaf B analysis, leaves were harvested at booting stage while grains were taken at final harvest. Both leaf and grain samples (5 g each) were oven-dried and grinded. Boron was analysed by dry ashing the grinded samples at $550^{\circ} \mathrm{C}$ for $4 \mathrm{~h}$, extracting the ash with $\mathrm{HCl}$ following Azomethine- $\mathrm{H}$ method (Malavolta et al., 1997).

The data were analyzed by analysis of variance technique using statistical package MSTATC and treatment means were compared using least significance difference (LSD) test at $5 \%$ probability (Steel et al., 1996). Graphical presentation of the data was made in Microsoft Excel. Correlation coefficients were derived using Microsoft Excel to substantiate the relationship between different variables.

\section{Results}

Foliar application of B substantially enhanced leaf elongation in both cultivars; however the response of both cultivars to different concentrations of B was different in this regard (Figure 1a, b). In Super Basmati, application of $0.16 \mathrm{M} \mathrm{B}$ was more effective in improving the elongation of $4^{\text {th }}$ leaf than control and other B treatments, whereas application of 0.48 M B was toxic, which decreased the leaf elongation even than control (Figure 1a). For $4^{\text {th }}$ leaf of Shaheen Basmati, all the B treatments improved the leaf elongation from 13 days after sowing (DAS), however, $0.32 \mathrm{M} \mathrm{B}$ was the best treatment in this regard followed by application of $0.24,0.40$ and $0.16 \mathrm{M} \mathrm{B}$ (Figure 1b). For $5^{\text {th }}$ leaf of Super Basmati, foliar application of $0.32 \mathrm{M} \mathrm{B}$ increased the leaf elongation than all other treatments (Figure 1b). In Shaheen Basmati, however, maximum elongation of 5th leaf was observed from the foliage application of $0.40 \mathrm{M} \mathrm{B}$ followed by application of $0.32 \mathrm{M} \mathrm{B}$ (Figure 1b).

In Super Basmati, from 14 DAS, B application improved the number of leaves (Figure 2a). In this regard, maximum leaf number was observed from application of $0.16 \mathrm{M} \mathrm{B}$ (Figure 2a).

In Shaheen Basmati, from 13 DAS, B application improved the number of leaves (Figure 2b). Maximum leaves were noted from application of $0.32 \mathrm{M} \mathrm{B}$ (Figure 2b). In both cultivars, B application improved the number of tillers; however, foliar application of $0.32 \mathrm{M} \mathrm{B}$ was more effective in this regard (Figure 3). 
Table 1. Weather data at Experimental station Faisalabad, Pakistan during 2009

\begin{tabular}{|c|c|c|c|c|c|c|}
\hline \multirow[t]{2}{*}{ Months } & \multirow{2}{*}{$\begin{array}{c}\text { Rainfall } \\
(\mathrm{mm})\end{array}$} & \multirow{2}{*}{$\begin{array}{c}\text { Relative } \\
\text { humidity } \\
(\%)\end{array}$} & \multicolumn{3}{|c|}{ Temperature $\left({ }^{\circ} \mathrm{C}\right)$} & \multirow[t]{2}{*}{ Sunshine (h) } \\
\hline & & & Daily maximum & Daily minimum & Daily mean & \\
\hline June & 1.0 & 40.0 & 40.1 & 27.7 & 33.9 & 9.38 \\
\hline July & 277.8 & 63.6 & 36.0 & 27.9 & 31.9 & 9.0 \\
\hline August & 22.6 & 74.6 & 34.9 & 26.1 & 30.5 & 6.0 \\
\hline September & 86.5 & 66.8 & 33.9 & 23.3 & 28.6 & 7.9 \\
\hline October & 0.0 & 59.6 & 32.9 & 19.7 & 26.3 & 7.6 \\
\hline November & 0.0 & 62.3 & 27.1 & 10.5 & 18.8 & 8.5 \\
\hline Average & 62.75 & 56.94 & 35.09 & 22.94 & 29.01 & 8.40 \\
\hline
\end{tabular}

Source: Agricultural Meteorology Cell, Department of Crop Physiology, University of Agriculture, Faisalabad, Pakistan
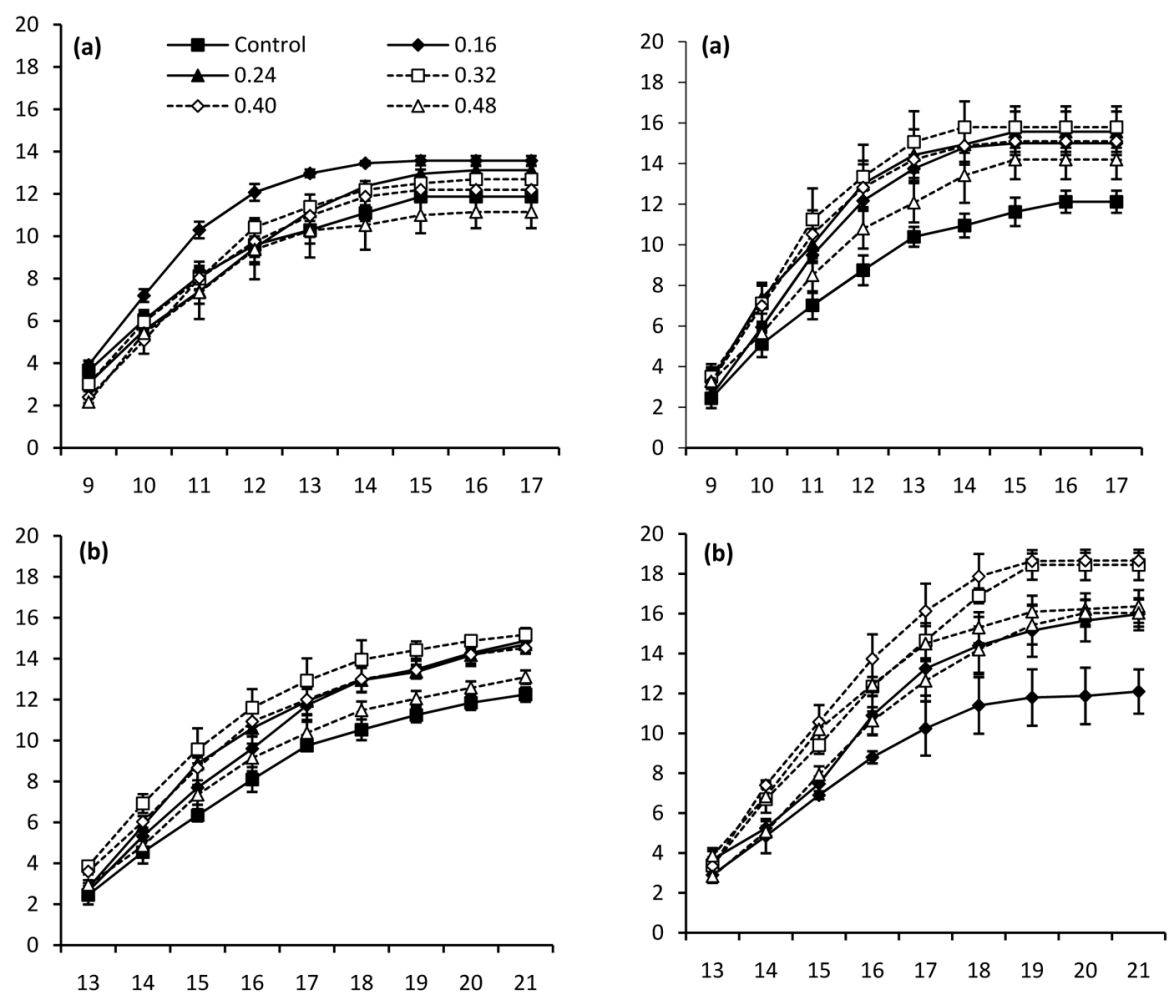

Figure 1. Influence of foliage applied boron on elongation of (a) fourth and (b) fifth leaf in rice cultivars Super Basmati and Shaheen Basmati during 2009. Vertical bars indicate standard error of means. 


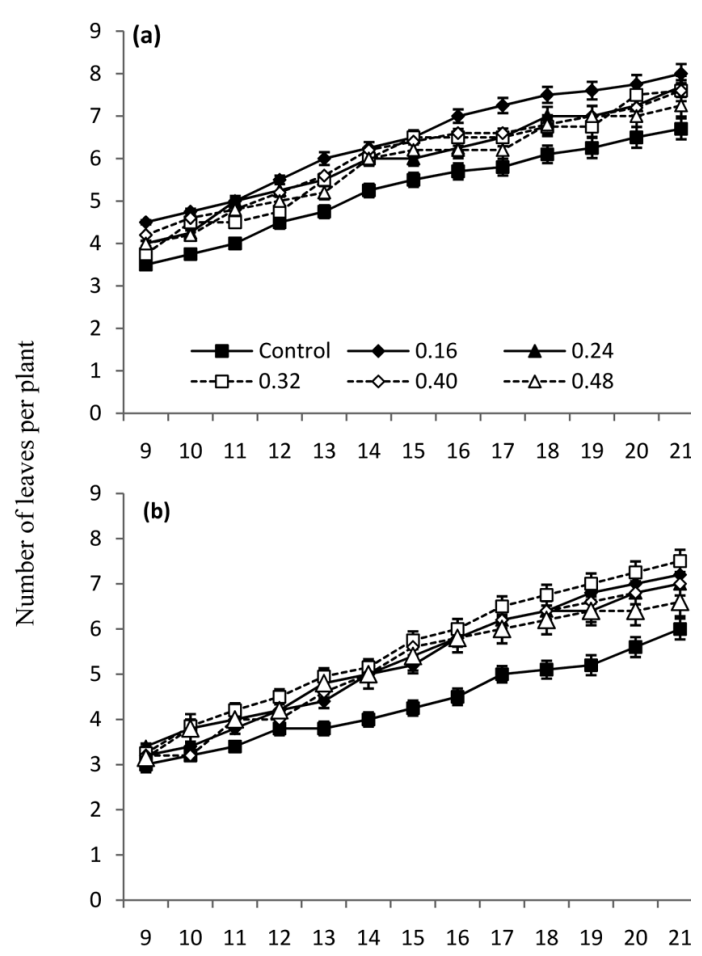

Days after sowing

Figure 2. Influence of foliage applied boron on leaf emergence rate in rice cultivars (a) Super Basmati and (b) Shaheen Basmati during 2009. Vertical bars indicate standard error of means.

Foliar applied B significantly affected the water relation attributes in both rice cultivars; however interactive effect of cultivars and B application was significant for leaf water potential $(\Psi \mathrm{w})$, osmotic potential $(\Psi \mathrm{s})$ and relative water contents (RWC) (Table 2). Maximum $\Psi_{\mathrm{W}}$ was recorded from foliar application of $0.32 \mathrm{M}$ $\mathrm{B}$ in Super Basmati followed by 0.40 and $0.48 \mathrm{M} \mathrm{B}$ in both cultivars (Table 2). Maximum $\Psi$ s was recorded with the application of $0.32 \mathrm{M} \mathrm{B}$ followed by 0.40 ,

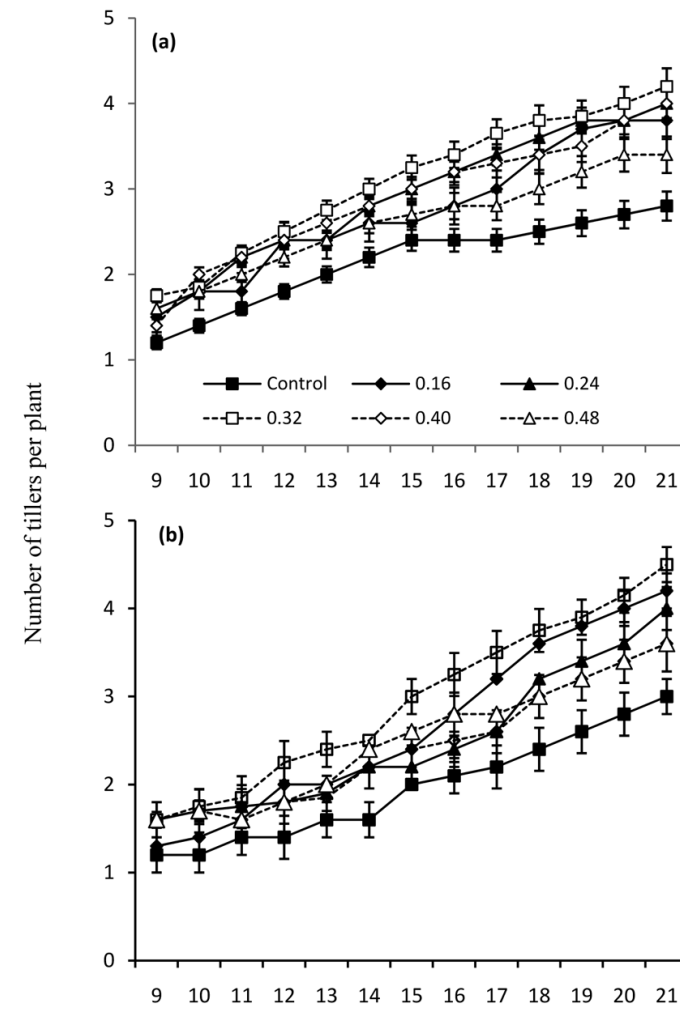

Days after sowing

Figure 3. Influence of foliage applied boron on tiller appearance in rice cultivars (a) Super Basmati and (b) Shaheen Basmati during 2009. Vertical bars indicate standard error of means.

0.48 and $0.24 \mathrm{M} \mathrm{B}$ in both rice cultivars. recorded with the application of $0.32 \mathrm{M} \mathrm{B}$ followed by $0.40,0.48$ and $0.24 \mathrm{M} \mathrm{B}$ in both rice cultivars. Foliar application of $0.40 \mathrm{M}$ B improved the pressure potential $(\Psi \mathrm{p})$ of both rice cultivars; it was followed by application of 0.32 and $0.48 \mathrm{M} \mathrm{B}$ (Table 2). Although, all B treatments improved RWC, maximum $\mathrm{RWC}$, in both rice cultivars, was recorded with the application of $0.48 \mathrm{M}$ $\mathrm{B}$ followed by 0.32 and $0.40 \mathrm{M} \mathrm{B}$ (Table 2). 
Table 2. Influence of foliar applied boron on water relations of rice cultivars Super Basmati (Super) and Shaheen Basmati (Shaheen)

\begin{tabular}{|c|c|c|c|c|c|c|c|c|c|c|c|c|}
\hline \multirow{2}{*}{$\begin{array}{l}\text { Treatments } \\
\text { (Molar boron) }\end{array}$} & \multicolumn{3}{|c|}{ Water potential $(-\mathrm{MPa})$} & \multicolumn{3}{|c|}{ Osmotic potential (-MPa) } & \multicolumn{3}{|c|}{ Pressure potential $(\mathrm{MPa})$} & \multicolumn{3}{|c|}{ Relative water contents (\%) } \\
\hline & Super & Shaheen & Mean & Super & Shaheen & Mean & Super & Shaheen & Mean & Super & Shaheen & Mean \\
\hline 0.00 & $2.16 \mathrm{ab}$ & $2.25 \mathrm{a}$ & $2.21 \mathrm{~A}$ & $2.60 \mathrm{ab}$ & $2.69 \mathrm{a}$ & $2.65 \mathrm{~A}$ & 0.44 & 0.43 & $0.44 \mathrm{AB}$ & $42.98 \mathrm{~d}$ & $44.88 \mathrm{~d}$ & $43.93 \mathrm{C}$ \\
\hline 0.16 & $1.94 \mathrm{abc}$ & $1.94 \mathrm{abc}$ & $1.94 \mathrm{AB}$ & $2.07 \mathrm{~cd}$ & $2.29 \mathrm{bc}$ & $2.18 \mathrm{~B}$ & 0.13 & 0.35 & $0.24 \mathrm{~B}$ & $53.26 \mathrm{c}$ & $55.33 \mathrm{c}$ & $54.29 \mathrm{~B}$ \\
\hline 0.24 & $1.80 \mathrm{bcd}$ & $1.71 \mathrm{cde}$ & $1.75 \mathrm{~B}$ & $2.06 \mathrm{~cd}$ & $1.93 \mathrm{~cd}$ & $1.99 \mathrm{BC}$ & 0.26 & 0.21 & $0.24 \mathrm{~B}$ & $56.68 \mathrm{bc}$ & $55.38 \mathrm{c}$ & $56.03 \mathrm{~B}$ \\
\hline 0.32 & $1.176 \mathrm{f}$ & $1.44 \mathrm{def}$ & $1.31 \mathrm{C}$ & $1.74 \mathrm{~d}$ & $1.88 \mathrm{~d}$ & $1.81 \mathrm{C}$ & 0.57 & 0.43 & $0.50 \mathrm{~A}$ & $65.13 \mathrm{a}$ & $63.65 \mathrm{a}$ & $64.39 \mathrm{~A}$ \\
\hline 0.40 & $1.30 \mathrm{ef}$ & $1.45 \mathrm{def}$ & $1.37 \mathrm{C}$ & $1.94 \mathrm{~cd}$ & $2.07 \mathrm{~cd}$ & $2.01 \mathrm{BC}$ & 0.64 & 0.63 & $0.63 \mathrm{~A}$ & $64.06 \mathrm{a}$ & $\begin{array}{l}03.26 \mathrm{ab} \\
62.26 \mathrm{~b}\end{array}$ & $63.16 \mathrm{~A}$ \\
\hline 0.48 & $1.33 \mathrm{ef}$ & $1.46 \mathrm{def}$ & $1.40 \mathrm{C}$ & $1.84 \mathrm{~d}$ & $1.97 \mathrm{~cd}$ & $1.91 \mathrm{C}$ & 0.51 & 0.51 & $0.51 \mathrm{~A}$ & $65.58 \mathrm{a}$ & $63.24 \mathrm{a}$ & $64.41 \mathrm{~A}$ \\
\hline Mean & 1.62 & 1.71 & & 2.04 & 2.14 & & 0.43 & 0.43 & & 57.95 & $\begin{array}{l}57.45 \\
5\end{array}$ & \\
\hline
\end{tabular}

Interaction and main effect means not sharing same letter for any trait differ significantly $(p<0.05)$

Likewise B application significantly affected the chlorophyll-a (Chl-a) and total Chl contents; interaction of cultivars and B application was significant only for total Chl (Table 3). However, influence of B application on Chl-b contents was not significant. Chl-a contents were significantly improved by foliar application of 0.24 to 0.48
M B (Table 3). Maximum total Chl contents were noted from foliar application of 0.16 M B in Super Basmati followed by $0.40,0.48$ and $0.24 \mathrm{M} \mathrm{B}$ in the same cultivar, and from application of 0.24 M B in Shaheen Basmati (Table 3). Super Basmati had higher contents of Chl-a and total Chl than Shaheen Basmati (Table 3).

Table 3. Influence of foliar applied boron on chlorophyll contents of rice cultivars Super Basmati (Super) and Shaheen Basmati (Shaheen)

\begin{tabular}{|c|c|c|c|c|c|c|c|c|c|}
\hline \multirow{2}{*}{$\begin{array}{l}\text { Treatments } \\
\text { (Molar boron) }\end{array}$} & \multicolumn{3}{|c|}{ Chlorophyll-a (mg g $\left.{ }^{-1} \mathrm{FW}\right)$} & \multicolumn{3}{|c|}{ Chlorophyll-b $\left(\mathrm{mg} \mathrm{g}^{-1} \mathrm{FW}\right)$} & \multicolumn{3}{|c|}{ Total chlorophyll $\left(\mathrm{mg} \mathrm{g}^{-1} \mathrm{FW}\right)$} \\
\hline & Super & Shaheen & Mean & Super & Shaheen & Mean & Super & Shaheen & Mean \\
\hline 0.00 & 3.00 & 2.56 & $2.78 \mathrm{C}$ & 1.42 & 1.32 & 1.37 & $4.44 \mathrm{bcd}$ & $3.89 \mathrm{~d}$ & $4.16 \mathrm{~B}$ \\
\hline 0.16 & 3.13 & 2.55 & $2.84 \mathrm{BC}$ & 2.14 & 1.52 & 1.83 & $5.29 \mathrm{a}$ & $4.08 \mathrm{~cd}$ & $4.69 \mathrm{~A}$ \\
\hline 0.24 & 3.25 & 3.03 & $3.14 \mathrm{~A}$ & 1.51 & 1.74 & 1.62 & $4.78 \mathrm{ab}$ & $4.79 \mathrm{ab}$ & $4.79 \mathrm{~A}$ \\
\hline 0.32 & 3.14 & 3.02 & $3.08 \mathrm{AB}$ & 1.42 & 1.40 & 1.41 & $4.58 b c$ & $4.44 \mathrm{bcd}$ & $4.51 \mathrm{AB}$ \\
\hline 0.40 & 3.17 & 3.03 & $3.10 \mathrm{AB}$ & 1.81 & 1.31 & 1.56 & $5.00 \mathrm{ab}$ & $4.36 \mathrm{bcd}$ & $4.68 \mathrm{~A}$ \\
\hline 0.48 & 3.10 & 2.68 & $2.89 \mathrm{ABC}$ & 1.71 & 1.38 & 1.54 & $4.83 \mathrm{ab}$ & $4.08 \mathrm{~cd}$ & $4.46 \mathrm{AB}$ \\
\hline Mean & $3.13 \mathrm{~A}$ & $2.81 \mathrm{~B}$ & & 1.67 & 1.44 & & $4.82 \mathrm{~A}$ & $4.27 \mathrm{~B}$ & \\
\hline
\end{tabular}

Interaction and main effect means not sharing same letter for any trait differ significantly $(p<0.05) \mathrm{SS}=\mathrm{Super}$ Basmati, $\mathrm{SB}=$ Shaheen Basmati

Boron application significantly improved the grain yield and yield-related parameters of both the tested cultivars; however interaction of cultivars with B application was significant for number of tillers and 1000-kernel weight (Table 4). Cultivars differed significantly only for 1000-kernel weight where Shaheen Basmati had more kernel weight than Super Basmati (Table 4). Among the yield components, maximum number of tillers was recorded from application of $0.24 \mathrm{M}$ B in both cultivars; maximum 1000-kernel weight, kernel yield per plant and minimum panicle sterility were recorded with foliage application of $0.32 \mathrm{M} \mathrm{B}$ (Table 4). Maximum 1000-kernel weight was observed from the application of $0.32 \mathrm{M} \mathrm{B}$ in Shaheen Basmati followed by application of $0.24 \mathrm{M}$ $\mathrm{B}$ in the same cultivar (Table 4). Likewise, maximum 
kernel yield per plant was recorded with application of $0.32 \mathrm{M} \mathrm{B}$ followed by application of 0.40 and 0.48 M B. Similarly, B application significantly decreased the panicle sterility; in this regard minimum sterility was recorded from application of 0.32 and $0.40 \mathrm{M} \mathrm{B}$ (Table 4).

Table 4. Influence of foliar applied boron on the grain yield and yield-related parameters of rice cultivars Super Basmati (Super) and Shaheen Basmati (Shaheen)

\begin{tabular}{|c|c|c|c|c|c|c|c|c|c|c|c|c|}
\hline \multirow{2}{*}{$\begin{array}{l}\text { Treatments } \\
\text { (Molar boron) }\end{array}$} & \multicolumn{3}{|c|}{ No. of tillers } & \multicolumn{3}{|c|}{ 1000-kernel weight (g) } & \multicolumn{3}{|c|}{ Kernel yield (g per plant) } & \multicolumn{3}{|c|}{ Panicle sterility (\%) } \\
\hline & Super & Shaheen & Mean & Super & Shaheen & Mean & Super & Shaheen & Mean & Super & Shaheen & Mean \\
\hline 0.00 & $17.00 \mathrm{abc}$ & $16.40 \mathrm{c}$ & $16.7 \mathrm{~B}$ & $16.82 \mathrm{e}$ & $16.95 \mathrm{de}$ & $16.89 \mathrm{D}$ & 36.50 & 36.06 & $36.28 \mathrm{C}$ & 12.26 & 12.26 & $12.26 \mathrm{~A}$ \\
\hline 0.16 & $20.00 \mathrm{abc}$ & $19.00 \mathrm{abc}$ & $19.5 \mathrm{~A}$ & $17.60 \mathrm{cde}$ & $18.17 \mathrm{bcde}$ & $17.88 \mathrm{CD}$ & 38.00 & 38.54 & $38.27 \mathrm{BC}$ & 7.79 & 9.06 & $8.43 \mathrm{~B}$ \\
\hline 0.24 & $20.60 \mathrm{a}$ & $20.40 \mathrm{ab}$ & $20.5 \mathrm{~A}$ & $17.72 \mathrm{cde}$ & $20.26 \mathrm{a}$ & $18.99 \mathrm{AB}$ & 38.80 & 40.05 & $39.43 \mathrm{~B}$ & 4.87 & 6.82 & $5.84 \mathrm{C}$ \\
\hline 0.32 & $20.40 \mathrm{ab}$ & $19.20 \mathrm{abc}$ & $19.8 \mathrm{~A}$ & $19.26 \mathrm{ab}$ & $20.49 \mathrm{a}$ & $19.88 \mathrm{~A}$ & 45.07 & 42.08 & $43.57 \mathrm{~A}$ & 3.20 & 3.19 & $3.19 \mathrm{D}$ \\
\hline 0.40 & $19.20 \mathrm{abc}$ & $17.80 \mathrm{abc}$ & $18.5 \mathrm{AB}$ & $19.03 \mathrm{abc}$ & $18.97 \mathrm{abc}$ & $19.00 \mathrm{AB}$ & 43.55 & 41.42 & $42.49 \mathrm{~A}$ & 3.75 & 2.63 & $3.19 \mathrm{D}$ \\
\hline 0.48 & $19.00 \mathrm{abc}$ & $16.60 \mathrm{bc}$ & $17.8 \mathrm{AB}$ & $18.42 \mathrm{bcd}$ & $18.97 \mathrm{abc}$ & $18.70 \mathrm{BC}$ & 43.79 & 41.23 & $42.51 \mathrm{~A}$ & 5.57 & 4.45 & $5.01 \mathrm{C}$ \\
\hline Mean & 19.37 & 18.23 & & 18.14B & $18.97 \mathrm{~A}$ & & 40.95 & 39.90 & & 6.24 & 6.40 & \\
\hline
\end{tabular}

Interaction and main effect means not sharing same letter for any trait differ significantly $(p<0.05)$

Boron application significantly improved the B contents in leaves and kernels; this improvement was increased with increase in $\mathrm{B}$ concentration of the solution applied in both cultivars (Table 5). However, cultivar Shaheen Basmati had more B contents in leaves and kernels than Super Basmati (Table 5).

Table 5. Influence of foliar applied boron on boron contents in leaf and grains of rice cultivars Super Basmati (Super) and Shaheen Basmati (Shaheen)

\begin{tabular}{ccccccc}
\hline \multirow{2}{*}{$\begin{array}{l}\text { Treatments } \\
\text { (Molar boron) }\end{array}$} & \multicolumn{2}{c}{ Leaf B contents $\left(\mathbf{m g ~ k g}^{-1}\right)$} & \multicolumn{2}{c}{ Kernel B contents $\left.\mathbf{~ m g ~ k g ~}^{-\mathbf{1}}\right)$} \\
\cline { 2 - 6 } & Super & Shaheen & Mean & Super & Shaheen & Mean \\
\hline 0.00 & 2.26 & 2.29 & $2.28 \mathrm{~F}$ & 1.41 & 1.47 & $1.44 \mathrm{~F}$ \\
0.16 & 2.56 & 2.68 & $2.63 \mathrm{E}$ & 1.68 & 1.76 & $1.73 \mathrm{E}$ \\
0.24 & 3.93 & 4.07 & $3.99 \mathrm{D}$ & 1.91 & 1.94 & $1.93 \mathrm{D}$ \\
0.32 & 4.52 & 4.56 & $4.54 \mathrm{C}$ & 2.06 & 2.15 & $2.11 \mathrm{C}$ \\
0.40 & 5.06 & 5.18 & $5.12 \mathrm{~B}$ & 2.21 & 2.26 & $2.23 \mathrm{~B}$ \\
0.48 & 5.38 & 5.49 & $5.44 \mathrm{~A}$ & 2.36 & 2.42 & $2.38 \mathrm{~A}$ \\
Mean & $3.95 \mathrm{~B}$ & $4.05 \mathrm{~A}$ & & $1.94 \mathrm{~B}$ & $1.99 \mathrm{~A}$ & \\
\hline
\end{tabular}

Interaction and main effect means not sharing same letter for any trait differ significantly $(p<0.05)$ 
There was strong negative correlation of panicle sterility with $\Psi \mathrm{w}, \Psi \mathrm{s}$, RWC and leaf B contents in both rice cultivars (Table 6). However, kernel yield and kernel $\mathrm{B}$ contents were positively correlated with $\Psi \mathrm{w}, \Psi \mathrm{s}, \mathrm{RWC}$ and leaf $\mathrm{B}$ contents in both rice cultivars (Table 6).

Table 6. Correlations coefficients (r) amongst different traits as affected by foliar applied boron in rice cultivars Super Basmati (Super) and Shaheen Basmati (Shaheen) $(n=5)$

\begin{tabular}{lcccccc}
\hline Variable & \multicolumn{2}{c}{ Panicle Sterility } & \multicolumn{2}{c}{ Kernel yield } & \multicolumn{2}{c}{ Kernel B contents } \\
\cline { 2 - 6 } & Super & Shaheen & Super & Shaheen & Super & Shaheen \\
\hline Water potential & $-0.87^{*}$ & $-0.99^{* *}$ & $0.99^{* *}$ & $0.99^{* *}$ & $0.90^{*}$ & $0.96^{* *}$ \\
Osmotic potential & $-0.93^{*}$ & $-0.86^{*}$ & $0.86^{*}$ & $0.94^{*}$ & $0.86^{*}$ & $0.83^{*}$ \\
Relative water contents & $-0.92^{*}$ & $-0.96^{* *}$ & $0.94^{*}$ & $0.97^{* *}$ & $0.96^{* *}$ & $0.94^{*}$ \\
Leaf B contents & $-0.82^{*}$ & $-0.92^{*}$ & $0.90^{*}$ & $0.90^{*}$ & $0.98^{* *}$ & $0.98^{* *}$ \\
\hline
\end{tabular}

$*=p<0.1, * *=p<0.01$

\section{Discussion}

Adequate supply of B through foliage application enhanced the performance of fine grain aromatic rice owing to improvement of leaf expansion and appearance (Figures 1, 2), tillering (Figures 3), water relations (Table 2), panicle fertility, kernel yield (Table 4) and grain B biofortification (Table 5). Foliar application of $0.32 \mathrm{M} \mathrm{B}$ was more effective for most of the studied attributes (Figures 1-3; Table 2-4). However, application of $0.16 \mathrm{M} \mathrm{B}$ was better for improvement in elongation of $4^{\text {th }}$ leaf (Figure 1a) and number of leaves in Super Basmati (Figure 2a), and $0.24 \mathrm{M} \mathrm{B}$ was better for Chl contents (Table 3) and number of tillers (Table 4) was more effective.

Substantial decrease in panicle sterility, and increase in grain size are the principal reasons of increase in kernel yield by foliage application of B (Table 4). Although primary role of $\mathrm{B}$ is to cross-link rhamnogalacturonan II monomers by a borate bridge, providing stability to the cell wall matrix (O'Neill et al., 1997); nonetheless, applied in small amounts is a critical component of membranes in pollen tubes (Jackson et al., 1989;
Bolanos et al., 2004). As growth of pollen tubes requires rapid synthesis of cell wall and plasma membrane (Taiz and Zeiger, 2010), B deficiency decreases the growth of pollen tube and fertilization thus causing failure of grain setting (Rerkasem et al., 1993). However, adequate supply of B ensures grain setting as indicated by decrease in panicle sterility (Table 4). A decrease in panicle sterility also seems due to some indirect effect of B. For instance, improvement in leaf water status by B application (Table 2), also contributed in reducing the panicle sterility as indicated by strong negative correlation of leaf water status traits with panicle sterility (Table 6). Low water status of panicle during anthesis has also been suggested as one of the reasons of panicle sterility in rice (Farooq et al., 2011). Adequate B supply may also help maintain the assimilate supply to the developing grains (Dixit et al., 2002) and increase the grain size as noted in this study (Table 4).

Boron foliar application showed a significant improvement in water status of both rice cultivars (Table 2). A few previous reports also affirm that B 
deficient leaves have poor water status than leaves with normal B nutrition (Baker et al., 1956; Dell and Huang, 1997; Rehman et al., 2012). Möttönen et al. (2001) ascribed this improvement to increased water uptake through B-induced increase in number of root tips and mycorrhizas.

Micronutrient malnutrition is a major human health problem in the developing world (Yang et al., 2007; Khan et al., 2010; Farooq et al., 2012); however, biofortification offers an attractive and economical solution of this important issue (Mao et al., 2014). Increase in kernel B contents by foliage application of $\mathrm{B}$ indicated that, other than breeding efforts, foliage application of micronutrients is also a pragmatic option (Table 5). Increase in leaf and grain B contents with increase in B concentration, in the solution applied, indicates that, if available, plants continue to partition it in the grains (Cheng and Rerkasem, 1993; Günes and Alpaslan, 2000).

\section{Conclusion}

In conclusion, $\mathrm{B}$ foliage application proved an effective way to correct B deficiency in rice. Improvement in grain yield by $\mathrm{B}$ application is attributed to increase in tillering and grain size and decrease in panicle sterility.

\section{Acknowledgments}

Financial support of Higher Education Commission, Pakistan for this study is acknowledged.

\section{References}

Arnon, D.T. 1949. Copper enzyme in isolated chloroplasts polyphenoloxidase in Beta vulgaris. Plant Physiol. 24, 1-15.
Baker, J.E., Gauch, H.G., Dugger, W.M. 1956. Effects of boron on the water relations of higher plants. Plant Physiol. 31, 89-94.

Blevins, D.G., Lukaszewski, K.M. 1998. Boron in plant structure and function. Annu. Rev. Plant Physiol. Plant Mol. Biol. 49, 481-500.

Bolanos, L., Lukaszewski K., Bonilla, I., Blevins, D. 2004. Why boron?. Plant Physiol. Biochem. 42, 907-912.

Cakmak, I., Römheld, V. 1997. Boron deficiencyinduced impairments of cellular functions in plants. Plant Soil. 193, 71-83.

Cheng, C.H., Rerkasem, B. 1993. Effects of boron on pollen viability in wheat. Plant Soil $155 / 156$, 313-315

Dell, B., Huang, L. 1997. Physiological response of plants to low boron. Plant Soil. 193, 103-120.

Dixit, D., Srivastava, N.K., Sharma, S. 2002. Boron deficiency induced changes in translocation of ${ }^{14} \mathrm{CO}_{2}$-photosynthate into primary metabolites in relation to essential oil and curcumin accumulation in turmeric (Curcuma longa L.). Photosynthetica. 40, 109-113.

Dunn, D., Stevens, G., Kendig, A. 2005. Boron fertilization of rice with soil and foliar applications. Online. Crop Management doi:10.1094/CM-20050210-01-RS.

Farooq, M., Siddique, K.H.M., Rehman, H., Aziz, T., Lee, D.J., Wahid, A. 2011. Rice direct seeding: experiences, challenges and opportunities. Soil Till. Res. 111, 87-98.

Farooq, M., Wahid, A., Siddique, K.H.M. 2012. Micronutrient application through seed treatments - a review. J. Soil Sci. Plant Nutri. 12, 125-142 
Goldberg, S. 1997. Reactions of boron with soils. Plant Soil. 193, 35-48

Günes, A., Alpaslan, M. 2000. Boron uptake and toxicity in maize genotypes in relation to boron and phosphorus supply. J. Plant Nutri. 23, 541-550

Hussain, M., Khan, M.A., Khan, M.B., Farooq, M., Farooq, S. 2012. Boron application improves the growth, yield and net economic return of rice. Rice Sci. 19, 259-262.

Jackson, J.F. 1989. Borate control of protein secretion for Petunia pollen exhibits critical temperature discontinuities. Sexual Plant Reprod. 2, 11-14

Khan, M.B., Farooq, M., Hussain, M., Shahnawaz, Shabir, G. 2010. Foliar application of micronutrients improves the wheat yield and net economic return. Int. J. Agri. Biol. 12, 953-956

Longbin, H., Pant, J., Dell, D., Bell, R.W. 2000. Effects of boron deficiency on anther development and floret fertility in wheat (Triticum aestivum L. 'Wilgoyne'). Ann. Bot. 85, 493-500.

Malavolta. E., Vitti, G.C., Oliveira, S.A. 1997. Evaluation of nutritional state of plants: principles and applications. (in Portuguese) Associação Brasileira para Pesquisa da Potassa e do Fosfato, Piracicaba, SP, Brazil.

Mao, H., Wang, J., Wang, Z., Zan, Y., Lyons, G., Zou, C. 2014. Using agronomic biofortification to boost zinc, selenium, and iodine concentrations of food crops grown on the loess plateau in China. J. Soil Sci. Plant Nutri. 14, 459-470.

Möttönen, M., Aphalo, P.J., Lehto, T. 2001. Role of boron in drought resistance in Norway spruce (Picea abies) seedlings. Tree Physiol. 21, 673-681.

O’Neill, M.A., Ishii, T., Albersheim, P., Darvill, A.G. 2004. Rhamnogalacturonan II structure and function of a borate cross-linked cell wall pectic polysaccharide. Annu. Rev. Plant Biol. 55, 109139.

Parr, A.J., Loughman, B.C. 1983. Boron and membrane function in plants. In: D.S. Robb, W.S. Pierpoint (eds.). Metals and Micronutrients, Uptake and Utilisation by Plants, pp. 87-107. Academic Press, New York.

Rashid, A., M. Yasin, M.A. Ali, Z. Ahmad, R. Ullah. 2009. Boron deficiency in rice in Pakistan: a serious constraint to productivity and grain quality. In: M. Ashraf, M. Ozturk, H.R. Athar (eds.). Salinity and Water Stress, pp. 213-219. SpringerVerlag, Berlin-Heidelberg, Germany.

Rehman, A., Farooq, M., Cheema, Z.A., Wahid, A. 2012. Seed priming with boron improves growth and yield of fine grain aromatic rice. Plant Growth Regul. 68, 189-201.

Rerkasem, B., Netsangtip, R., Lordkaew, S., Cheng, C. 1993. Grain set failure in boron deficient wheat. Plant Soil 155/156, 309-312.

Sharma, C.P., Sharma, P.N. 1987. Mineral nutrient deficiencies affect plant water relations. J. Plant Nutr. 10, 1637-1643.

Sheng, O., Song, S., Peng, S., Deng, X. 2009. The effects of low boron on growth, gas exchange, boron concentration and distribution of 'Newhall' navel orange (Citrus sinensis Osb.) plants grafted on two rootstocks. Scientia Hort. 121, 278-283.

Shorrocks, V.M. 1997. The occurrence and correction of boron deficiency. Plant Soil. 193, 121-148.

Sprague, H.B. 1951. Hunger Signs in Crops. McKay, New York, USA.

Steel, R.G.D., Torrie, J.H., Dickey, D. 1996. Principles and procedures of statistics: a biometric approach, 3rd Ed. McGraw Hill Book Co. Inc., New York. USA. 
Taiz, L., Zeiger, E. 2010. Plant Physiology, $5^{\text {th }}$ Edition. Sinauer Associates, Inc., Sunderland, MA.
Yang, X.E., Chen, W.R., Feng, Y. 2007. Improving human micronutrient nutrition through biofortification in the soil-plant system: China as a case study. Environ. Geochem. Health. 29, 413-428. 